\section{International Scientific Journal Theoretical \& Applied Science}

p-ISSN: 2308-4944 (print) e-ISSN: 2409-0085 (online)

Year: $2016 \quad$ Issue: $10 \quad$ Volume: 42
Ivan Borisovich Krylov Head of Information Technology Research Library, applicant Orenburg State University, Russia, Orenburg krilovib@mail.ru

Published: $30.10 .2016 \quad \underline{\text { http://T-Science.org }}$

SECTION 4. Computer science, computer engineering and automation.

\title{
THE ALGORITHM OF BUILDING OF INDIVIDUAL LEARNING PATH IN MULTIAGENT INTELLIGENT TEACHING SYSTEM
}

Abstract: This work proves the applicability of development of multiagent intelligent teaching systems. It shows the necessity of teaching systems development that allow to adopt the teaching process to trainees' cognitive-psychological makers from the first minutes of working with system. There was designed the conceptual modal of adaptable control on teaching system showed in weighted graph. It was developed the algorithm of individual teaching path building on the base of Mamdani fuzzy inference. It was made the approbation and testing of software with this developed algorithm.

Key words: multiagent intelligent teaching system, individual teaching path, adaptable control on teaching process.

Language: English

Citation: Krylov IB (2016) THE ALGORITHM OF BUILDING OF INDIVIDUAL LEARNING PATH IN MULTIAGENT INTELLIGENT TEACHING SYSTEM. ISJ Theoretical \& Applied Science, 10 (42): 29-33.

Soi: http://s-o-i.org/1.1/TAS-10-42-7 Doi: crostef http://dx.doi.org/10.15863/TAS.2016.10.42.7

\section{Introduction}

For the moment in education system there is the mainstreaming and usage of information and communication technologies in teaching process. Intelligent teaching systems (ITS) [1] that allow adopting the teaching process to trainees' cognitivepsychological makers from the first minutes of working with system become popular [2]. Much prominence is given to ITS keeping the technologies of on-line learning. The number of users of such systems is increasing. That's why the impacts on hardware and computer network is growing, work stability is decreasing and development of ITS becomes more complicated. Therefore multiagent ITS become popular.

Multiagent ITS have a variety of advantages comparing with ITS developed on the base of another approaches (object-oriented, event-driven and others). Main advantages are:

- decreasing of impacts on hardware and computer network;
- system flexibility by addition of new agents to existing architecture without any change in the whole operation algorithm [3];

- opportunity to solve hard formalized problems where the defining algorithm of system functioning is unknown.

\section{Materials and Methods}

Essential concept of multiagent approach is the definition of an «agent». M. Wooldridge and N. Jennings in their work [4] give the following definition of an agent: an agent is the computation system placed in outdoor environment and interacting with it making independent reasonable actions for achieving the goal by that.

For graphical representation of adaptable control on teaching process in multiagent ITS they used the method of model designing of Bolotova (Zagadskaya) L.S. topical area [5]. As the result it was built the conceptual model of adoptable controle on teaching process showed as weighted graph (picture 1). 


\begin{tabular}{|c|c|c|c|c|c|c|}
\hline Impact Factor: & $\begin{array}{l}\text { ISRA (India) } \\
\text { ISI (Dubai, UAE } \\
\text { GIF (Australia) } \\
\text { JIF }\end{array}$ & $\begin{array}{r}=1.344 \\
=0.829 \\
=0.564 \\
=1.500\end{array}$ & $\begin{array}{l}\text { SIS (USA) } \\
\text { PИНЦ (Russia) } \\
\text { ESJI (KZ) } \\
\text { SJIF (Morocco) }\end{array}$ & $\begin{array}{l}=0.912 \\
=0.234 \\
=1.042 \\
=2.031\end{array}$ & $\begin{array}{l}\text { ICV (Poland) } \\
\text { PIF (India) } \\
\text { IBI (India) }\end{array}$ & $\begin{array}{l}=6.630 \\
=1.940 \\
=4.260\end{array}$ \\
\hline
\end{tabular}

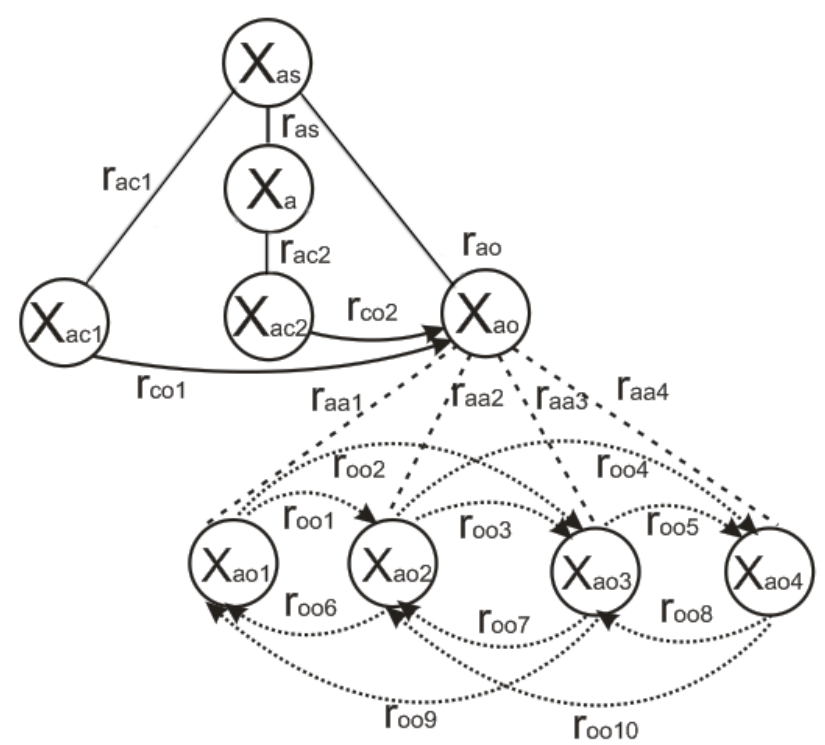

Picture 1 - Conceptual model of adoptable control on teaching process.

In this case $X_{a s}$ - ITS, $X_{a}$ - action «select the individual teaching path», $X_{a c l}$ - agent of formation of individual teaching path (ITP), $X_{a c 2}$ - correcting agent ITP, $X_{a o}$ - teaching path, $X_{a o 1}, \ldots, X_{a o 2}-$ possible teaching paths, $r_{a s}$ - relation between ITS and action «select the individual teaching path», $r_{a c l}$, $r_{a c 2}$ - relation between the action and the corresponding agent, $r_{a o}-$ relation between the action and the ITP, $r_{c o l}, r_{c O 2}$ - the relation between the corresponding agent and the ITP, $r_{a a l}, \ldots, r_{a a 4}-$ structural relation between the teaching path with each of potential paths, $r_{o o l}, \ldots, r_{o o l 0}-$ possible transitions between ITPs.

The formation of ITP is made by the formation agent of ITP. ITP is defined as the combination of following dimensions: the choice of teaching sequence $V_{p}$, the chance to finish topic studying $V_{z}$, and is expressed as:

$$
X_{a o}=\left(V_{p}, V_{z}\right)
$$

Consequently ITP can be expressed as one of the following pairs:

- ("absence of choice», "after completing the beginning level of difficulty exercises») - «I path»;

- ("absence of choice», "after completing the beginning and intermediate level of difficulty exercises») - «II path»;

- ("partitive choice», «after completing the beginning and intermediate level of difficulty exercises») - «III path»;

- ("full choice», "rafter completing all level of difficulty exercises») - «IV path».

The algorithm of ITP building is realized on the base of Mandani fuzzy inference. The review and explanations of choice of mathematical method and multiagent ITS for realization of adaptable control on teaching process are presented in work [6].

«Motivation level» and «rudiment level» were chosen as input linguistic variables and «individual teaching path» as output linguistic variable. Knowledge base on the base of productive model [7] was designed for software implementation of developed ITP formation algorithm:

IF $\left(x_{1}-\left\langle\right.\right.$ low») AND ( $x_{2}-\langle$ insufficient») THEN $y=\langle\mathrm{I}$ path $» ;$

IF $\left(x_{1}-\ll h i g h »\right)$ AND $\left(x_{2}-\right.$ «insufficient») THEN $y=\ll I I$ path»;

IF $\left(x_{1}-\ll\right.$ low» $)$ AND $\left(x_{2}-\right.$ «sufficient») THEN $y=\langle$ III path»;

IF $\left(x_{1}-\left\langle\right.\right.$ «high») AND ( $x_{2}-$ «sufficient») THEN $y=\ll \mathrm{IV}$ path».

In this case: $x_{1}$ - motivation level; $x_{2}$ - beginner level; $y$ - teaching path.

The realization of fussy inference algorithm was made in the following sequence of operating actions [8]:

1. The identification of supposition truth degree for each rule. Gauss function was chosen for each term of membership function:

$$
\mu_{i}\left(x_{i}\right)=\frac{1}{1+\left(\frac{x_{i}-c^{i}}{\sigma^{i}}\right)^{2 b^{i}}} .
$$

where $c^{i}, \sigma^{i}, b^{i}$ - membership function parameter, defined by experts.

2. Aggregation of truth degree based on minconjunction:

$$
\mu_{A_{i 1} \wedge A_{i 2}}(x)=\min \left(\mu_{A_{i 1}}\left(x_{1}\right), \mu_{A_{i 2}}\left(x_{2}\right)\right)
$$




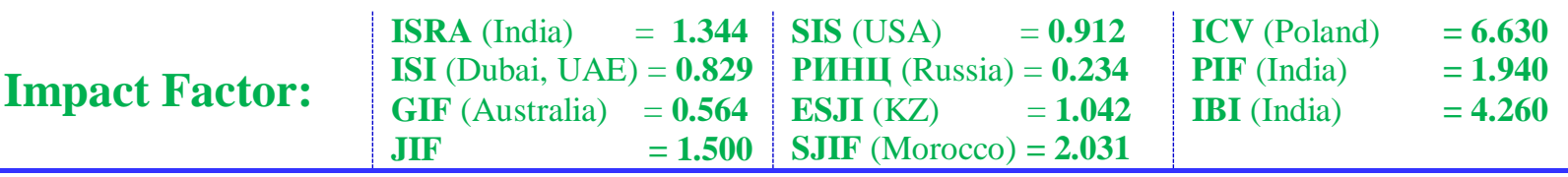

3. Identification of truth degrees of conclusion on each of the rules based on operations minactivisation:

$$
\mu_{B_{i}^{\prime}}(y)=\min \left(\mu_{A_{i}}(x), \mu_{B_{i}}(y)\right)
$$

. Accumulation of received on previous stage conclusions with max-disjunction:

$$
\mu_{B^{\prime}}(y)=\max \left\{\mu_{B_{i}^{\prime}}(y)\right\}, i=\overline{1,5}
$$

5. Reducing to precision by centroid method (discrete version):

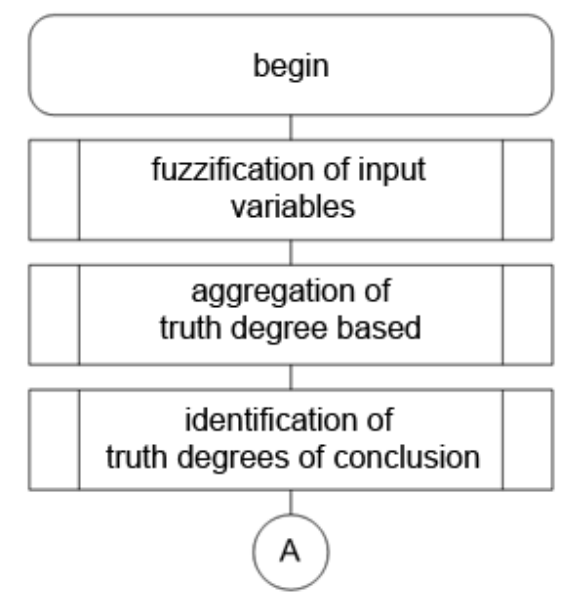

Picture 2 - Algorithm of individual teaching path building.

The developed algorithm of adoptable control on teaching process is realized in the software «The program of modeling of adoptable control on

$$
y^{\prime}=\frac{\sum_{r=0}^{1} y_{r} \mu_{B^{\prime}}\left(y_{r}\right)}{\sum_{r=0}^{1} \mu_{B^{\prime}}\left(y_{r}\right)}
$$

6. The definition of term of output variable «individual teaching path» with the maximum membership function value from calculated numeric value on the previous level:

$$
y^{\prime \prime}=\max \left\{\mu_{B_{i}}\left(y^{\prime}\right)\right\}, i=\overline{1,5}
$$

The scheme of developed algorithm is shown on picture 2 .

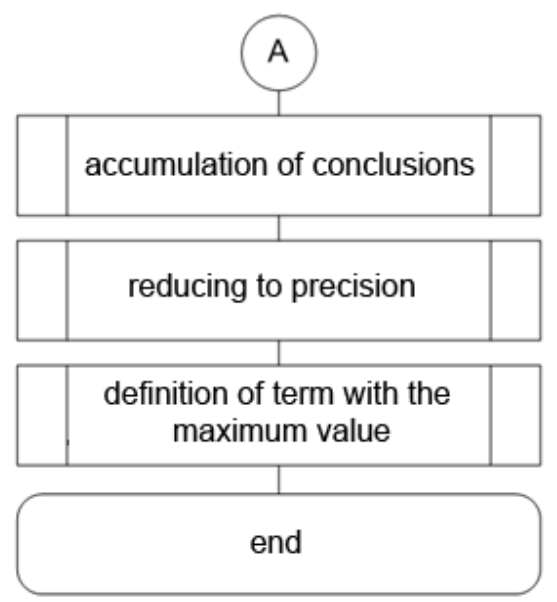

teaching process»» (pictures 3, 4), registered in Russian Federal Agency for intellectual Property, Patents and Trademarks [9].

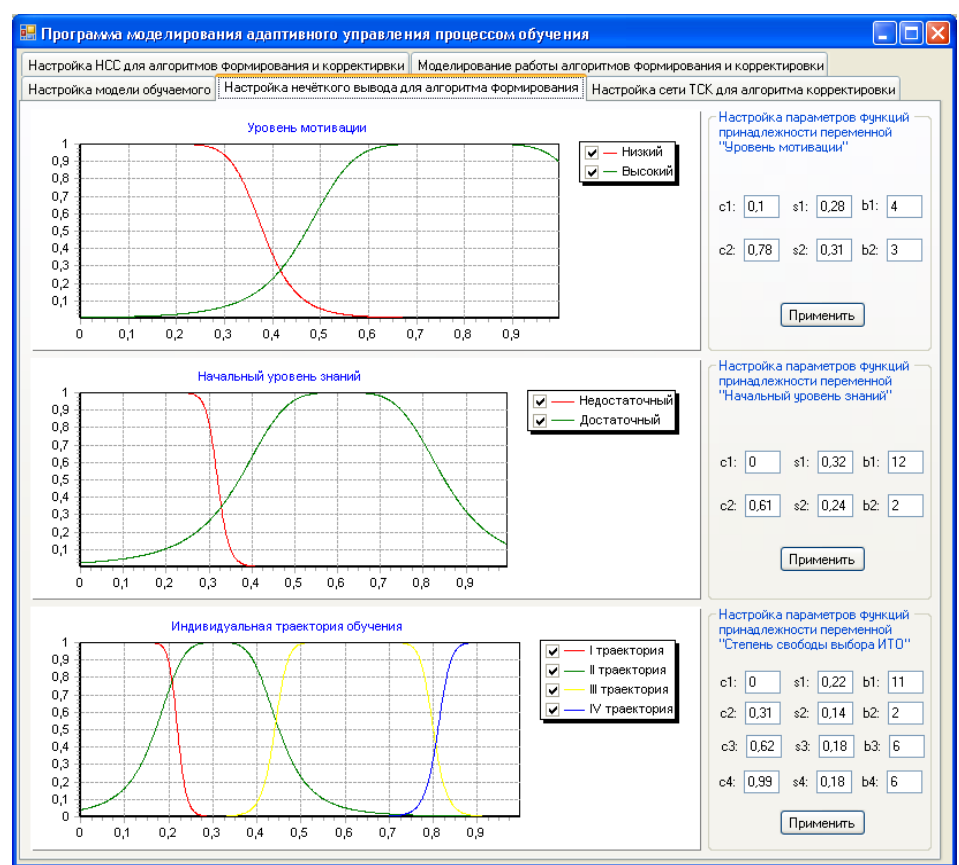

Picture 3 - Membership function parameter setting in program of modeling of adoptable control on teaching process.

ISPC Computer technologies in science, Scranton, USA 


\begin{tabular}{l|lr|ll|ll} 
& ISRA (India) & $=\mathbf{1 . 3 4 4}$ & SIS (USA) & $=\mathbf{0 . 9 1 2}$ & ICV (Poland) & $=\mathbf{6 . 6 3 0}$ \\
Impact Factor: & ISI (Dubai, UAE) $=\mathbf{0 . 8 2 9}$ & PUHЦ (Russia) $=\mathbf{0 . 2 3 4}$ & PIF (India) & $=\mathbf{1 . 9 4 0}$ \\
& GIF (Australia) & $\mathbf{0 . 5 6 4}$ & ESJI (KZ) & $=\mathbf{1 . 0 4 2}$ & IBI (India) & $=\mathbf{4 . 2 6 0}$ \\
& JIF & $=\mathbf{1 . 5 0 0}$ & SJIF (Morocco) & $\mathbf{2 . 0 3 1}$ & & \\
\hline
\end{tabular}

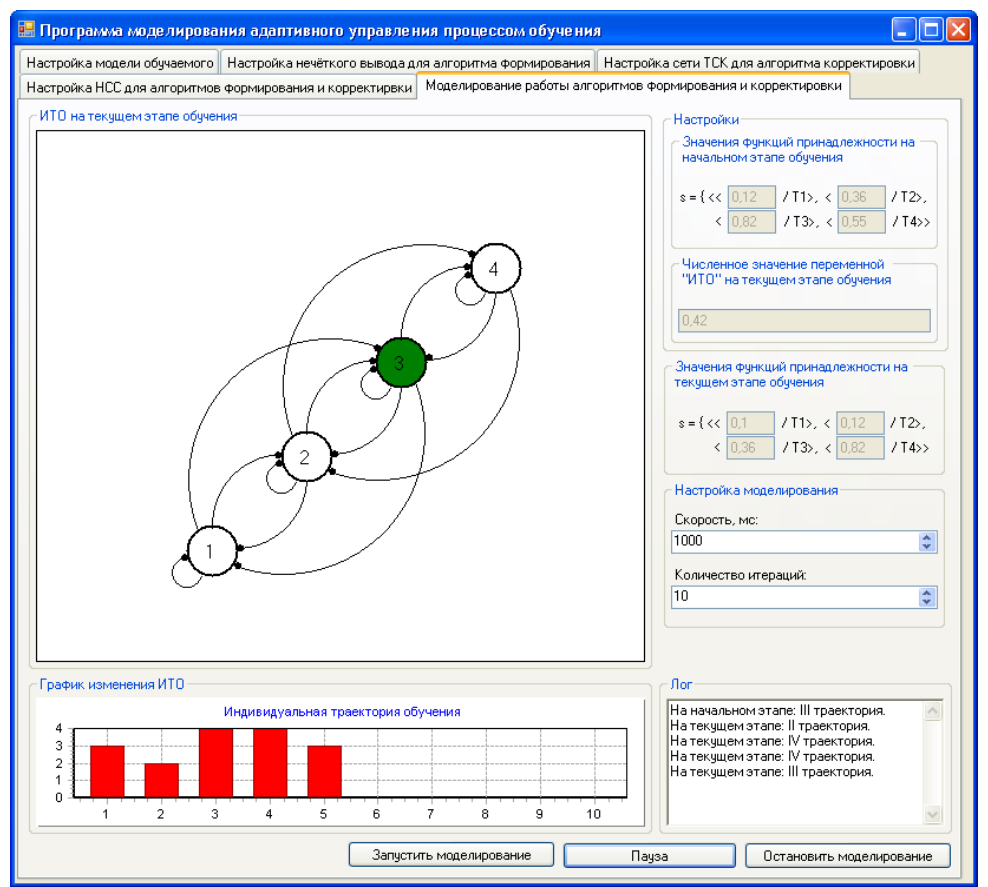

Picture 4 - The results of work program in modeling of adoptable control on teaching process.

\section{Conclusion}

The results of approbation and testing of software prove the high effectiveness of developed algorithm work.
Hereafter it is planned to develop a multiagent ITS on the base of previously developed program in discipline «Fundamentals of Management Theory» [10], in which offered formation and correcting ITS algorithms will be realized.

\section{References:}

1. Semenova NG (2015) Razrabotka agentnoorientirovannoj intellektual'noj obuchajushhej sistemy na osnove nechjotkoj nejronnoj seti Takagi-Sugeno-Kanga. Vektor nauki Tol'jattinskogo gosudarstvennogo universiteta. N. 2 (32), pp. 158-166.

2. Yurkov NK (2010) Intellektual'nye komp'juternye obuchajushhie sistemy: monografija. Penza : PGU, 304 p.

3. Ricci A, Piunti M, Viroli M (2011) Environment programming in multi-agent systems: an artifact-based perspective. Autonomous Agents and Multi-Agent Systems. V. 23, pp. 158-192.

4. Wooldridge M, Jennings N (1995) Intelligent Agents: Theory and Practice. Knowledge Engineering Review. N. 10 (2), pp. 115-152.
5. Bolotova LS (2012) Sistemy iskusstvennogo intellekta: modeli $\mathrm{i}$ tehnologii, osnovannye na znanijah. Moskva: Finansy i statistika, 664 p, ISBN 978-5-27903-530-4.

6. Krylov IB (2014) Matematicheskie metody i mul'tiagentnyj podhod, primenjaemye pri razrabotke intellektual'noj obuchajushhej sistemy tehnicheskoj discipliny. Vserossijskaja nauchno-metodicheskaja konferencija (s mezhdunarodnym uchastiem) «Universitetskij kompleks kak regional'nyj centr obrazovanija, nauki i kul'tury», pp. 333-336.

7. Melihov AN, Bershtejn LS, Korovin SY (1990) Situacionnye sovetujushhie sistemy s nechjotkoj logikoj. M.: Nauka, 272 p, ISBN 5-02-014144-5. 


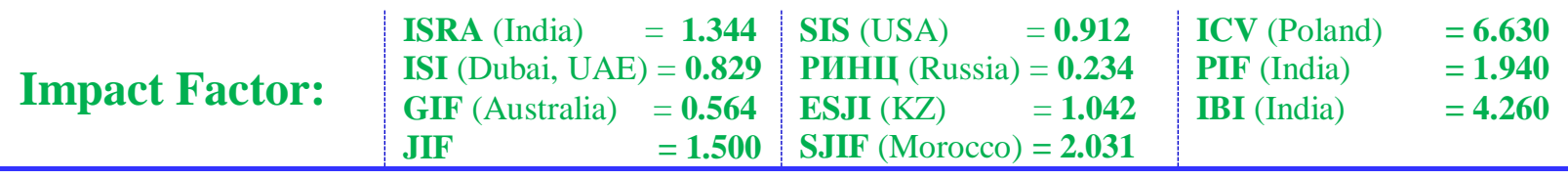

8. Borisov VV, Kruglov VV, Fedulov AS (2007) Nechjotkie modeli i seti. M: Gorjachaja linija-Telekom, 284 p, ISBN 593517-278-X.

9. Krylov IB (2016) Programma modelirovanija adaptivnogo upravlenija processom obuchenija [El. resurs].

10. Krylov IB (2016) Adaptivnaja obuchajushhaja programma po discipline "Osnovy teorii upravlenija" [El. resurs]. Svidetel'stvo o gosudarstvennoj registracii programmy dlja JVM N. 2016614209. - M.: Rospatent.

Svidetel'stvo o gosudarstvennoj registracii programmy dlja JVM N. 2016614210. - M.:

Rospatent. 